\title{
Sleep apnea and its role in transportation safety [version 1;
}

\section{peer review: 3 approved]}

\author{
Maria Bonsignore (iD) 1,2
}

${ }^{1}$ DiBiMIS, University of Palermo, Palermo, Italy

${ }^{2}$ CNR Institute of Biomedicine and Molecular Immunology (IBIM), Palermo, Italy

V1 First published: 22 Dec 2017, 6(F1000 Faculty Rev):2168

https://doi.org/10.12688/f1000research.12599.1

Latest published: 22 Dec 2017, 6(F1000 Faculty Rev):2168

https://doi.org/10.12688/f1000research.12599.1

\section{Abstract}

Obstructive sleep apnea (OSA) is a main cause of excessive daytime sleepiness and increases the risk for driving accidents, which can be normalized by treatment with continuous positive airway pressure ventilation. Since it is estimated that OSA is not diagnosed in about $80 \%$ of cases, recognition of patients at risk for driving accidents is a problem from both medical and societal points of view. Strategies to screen and identify subjects at high risk for driving accidents are under study in order to improve safety on the road, especially for commercial drivers, who show a high prevalence of OSA.

\section{Keywords}

Obstructive Sleep Apnea, Sleep disorders, CPAP, driving accidents
Open Peer Review

Approval Status

12

23

version 1

22 Dec 2017

Faculty Reviews are review articles written by the prestigious Members of Faculty Opinions. The articles are commissioned and peer reviewed before publication to ensure that the final, published version is comprehensive and accessible. The reviewers who approved the final version are listed with their names and affiliations.

1. Mark Elliott, St James University Hospital, Leeds, UK

2. Joaquin Terán Santos, Hospital Universitario de Burgos, Burgos, Spain

3. Luigi Ferini-Strambi, Università Vita-Salute

San Raffaele, Milan, Italy

Any comments on the article can be found at the end of the article. 
Corresponding author: Maria Bonsignore (marisa@ibim.cnr.it)

Author roles: Bonsignore M: Conceptualization, Writing - Original Draft Preparation, Writing - Review \& Editing

Competing interests: No competing interests were disclosed.

Grant information: The author(s) declared that no grants were involved in supporting this work.

Copyright: (c) 2017 Bonsignore M. This is an open access article distributed under the terms of the Creative Commons Attribution License, which permits unrestricted use, distribution, and reproduction in any medium, provided the original work is properly cited.

How to cite this article: Bonsignore M. Sleep apnea and its role in transportation safety [version 1; peer review: 3 approved] F1000Research 2017, 6(F1000 Faculty Rev):2168 https://doi.org/10.12688/f1000research.12599.1

First published: 22 Dec 2017, 6(F1000 Faculty Rev):2168 https://doi.org/10.12688/f1000research.12599.1 
OSA is characterized by partial (hypopnea) or complete (apnea) collapse of upper airway during sleep, causing intermittent hypoxemia and sleep fragmentation. Respiratory pauses during sleep referred by the partner, intermittent snoring, and excessive daytime sleepiness (EDS) are the most frequent OSA symptoms, but the clinical picture may vary. Subjective EDS is reported by only $50 \%$ of patients with OSA ${ }^{1}$. OSA severity is defined as the number of respiratory events per hour of sleep (apnea-hypopnea index, or AHI). Mild, moderate, and severe OSA are defined on the basis of AHI cutoffs of 5 to less than 15 , 15 to less than 30 , and 30 or more, respectively ${ }^{1}$.

OSA is the most frequent type of sleep-disordered breathing in the adult general population. OSA is often associated with obesity but can occur in normal-weight subjects. Both anatomical and functional factors contribute to the pathogenesis of upper airway collapse during sleep ${ }^{2}$. OSA prevalence increases with age and body mass index and is higher in men than in women. According to a recent meta-analysis, the prevalence of OSA in the general population ranges between $9 \%$ and $38 \%$ for an AHI cutoff of at least five events per hour ${ }^{3}$. The HypnoLaus study in over 2,000 subjects from the general population in Lausanne reported much higher prevalences of moderate to severe OSA (AHI $\geq 15$ per hour): $23.4 \%$ in women and $49.7 \%$ in men ${ }^{4}$.

The gold standard of OSA treatment is continuous positive airway pressure (CPAP) during sleep, manually or automatically titrated to the therapeutic level in each patient. Application of CPAP prevents upper airway collapse and all the health consequences of OSA ${ }^{1}$. Adherence to CPAP treatment, however, is often suboptimal, especially in patients with mild or no OSA symptoms. Currently, the use of CPAP for at least 4 hours per night for $70 \%$ of nights is considered evidence of good adherence ${ }^{5}$, although more prolonged use is necessary to prevent the full spectrum of OSA-associated derangements ${ }^{6}$. Other treatment modalities are available. Mandibular advancement devices are often preferred by patients but are more effective in mild to moderate than in severe $\mathrm{OSA}^{7}$. Upper airway surgery is an additional option, but the success rate is highly variable ${ }^{8}$. In obese patients, lifestyle interventions and bariatric surgery are associated with a reduction of AHI, although a complete resolution of OSA may be difficult to achieve?

OSA is often associated with systemic hypertension and cardiovascular comorbidities. Severe untreated OSA increases the risk for all-cause and cardiovascular mortality ${ }^{10}$. Data from the Sleep and Stent Study, a longitudinal observational study in patients undergoing percutaneous coronary interventions, showed an independent association between OSA and incidence of major adverse cardiac and cerebrovascular events during follow-up ${ }^{11}$. However, recent randomized controlled trials failed to confirm any significant effect of CPAP treatment in minimally symptomatic patients with coronary artery disease and OSA ${ }^{12,13}$. A recent meta-analysis found a significant protective effect of CPAP only in patients who used CPAP for more than 4 hours per night ${ }^{14}$. According to these data, CPAP treatment might be indicated more for control of symptoms than for prevention of
OSA-associated risk, since low compliance to CPAP treatment remains a problem in asymptomatic patients.

EDS is associated with increased risk of motor vehicle accidents and a high rate of fatal accidents ${ }^{15}$. OSA is not the only cause of EDS, since sleep deprivation and shift work also contribute to sleepiness at the wheel. A survey promoted by the European Sleep Research Society (over 12,000 questionnaires obtained from 19 countries) reported the alarming result that $17 \%$ of respondents had fallen asleep at the wheel in the previous 2 years ${ }^{16}$. Individual factors predicting sleepiness at the wheel were younger age, male gender, driving at least 20,000 km per year, higher EDS, and high risk for OSA assessed by questionnaire. Compared with controls, patients with OSA show a 2.5-fold risk for car accidents $^{17}$ and occupational accidents ${ }^{18,19}$. In the European Sleep Apnea Database (ESADA) cohort, driving risk increased with OSA severity; interestingly, obesity, short sleep time, and younger age were associated with high driving distance per year ${ }^{20}$. A longitudinal study on driving accidents, based on data derived from the Sweden Traffic Accidents Registry, found that OSA severity did not predict accidents, and significant risk factors were driving distance, EDS, habitual sleep shorter than 5 hours per night, and use of hypnotics. In patients with OSA, treatment with CPAP with good adherence was found to normalize the risk for accidents ${ }^{21}$.

Although the role of OSA in driving accidents has been known for about 20 years, it has regained attention recently because of the need to increase safety on the road. In 2014, a European Union (EU) regulation for the first time set the requirements for issuing a driver's license to patients with moderate to severe $\mathrm{OSA}^{22}$. Since EDS and driving risk in OSA can be reversed to normal after treatment with $\mathrm{CPAP}^{23,24}$, the EU Directive mandates objective assessment of compliance to CPAP in treated OSA patients. A driver's license can be issued to patients with objectively documented good adherence to CPAP treatment, and reassessment of fitness to drive and compliance to treatment is planned at 3-year intervals in noncommercial drivers and after 1 year in commercial drivers ${ }^{22}$. However, symptomatic cases represent only a small fraction of the subjects with significant sleep-disordered breathing, since comparison between epidemiological data and actually identified OSA patients indicates that OSA remains undiagnosed in about $80 \%$ of cases.

The attitude for management of OSA patients with regard to issuing a driver's license is highly variable. A survey of British doctors highlighted large disagreement in the evaluation of sleepiness and driving risk in patients with OSA and variable levels of acceptable compliance to CPAP treatment with regard to driving risk $^{25}$. In addition, the medical personnel in charge of the evaluation varies in different countries, from the pulmonologist to the sleep specialist or the personnel of the national agency issuing the driver's license. In summary, a clear model applicable in a standardized way in different countries is still lacking, and its implementation will require a considerable educational effort to instruct the health service personnel about screening for OSA and identifying patients potentially at high risk for accidents. 
The issue of safety is particularly relevant in commercial drivers, who show a higher prevalence of OSA (between $28 \%$ and $78 \%$ ) compared with the general population and are more exposed to risk of driving accidents because of their high mileage per year compared with noncommercial drivers ${ }^{26}$. Accordingly, commercial drivers should be subjected to tighter control of their health status, including OSA screening and assessment. The American Academy of Sleep Medicine has issued a comprehensive and detailed document on screening and diagnostic and therapeutic approaches for commercial drivers ${ }^{26}$. This document underlines the cost-effectiveness of OSA treatment and the substantial savings associated with CPAP treatment and the related prevention of drowsiness-related accidents. Moreover, OSA treatment improved the amount and quality of sleep, quality of life, and overall health costs ${ }^{26}$.

A recent study reported the effect of a screening program promoted by the transportation industry with the aim to detect and treat OSA in commercial drivers and monitor the frequency of accidents according to adherence to treatment ${ }^{27}$. This study confirmed a high risk associated with untreated severe OSA in commercial drivers (that is, a fivefold risk in drivers with OSA nonadherent to CPAP treatment compared with controls) and the protective effect of CPAP treatment (that is, similar accident rate in non-OSA and CPAP-adherent drivers with OSA $)^{27}$. Nevertheless, only $46 \%$ of drivers with OSA on CPAP showed good adherence to treatment. This longitudinal study, the first specifically focused on commercial drivers, raised a number of questions on the best strategy to improve driving safety and, as underlined in the accompanying editorial ${ }^{28}$, highlights the difficulties in developing a feasible set of legal rules to be applied in daily practice on a large scale to avoid a major risk for humans and significant property damage.

OSA represents a relevant risk for car accidents because of its rising prevalence in the population in association with the obesity epidemic. Unlike alcohol drinking, which can be readily identified by the police through an immediate measurement of the blood alcohol level, sleepiness of drivers at the wheel is impossible to identify in a straightforward way. Therefore, a screening strategy can be implemented only when the driver's license is issued or renewed, as indicated by the EU Directive; this document, however, does not indicate any specific protocol to be followed, and national regulations have to be developed and implemented by each member state. To date, only the Spanish Sleep Society in Europe has published an updated protocol to address the issuing or renewing of drivers' licenses according to the EU Directive ${ }^{29}$.

The current screening strategy relies on validated questionnaires to identify subjects at risk for OSA requiring further investigation. A recent meta-analysis compared sensitivity, specificity, and diagnostic odds ratio of the Berlin, STOP-Bang, STOP, and Epworth Sleepiness Scale (ESS) questionnaires ${ }^{30-33}$, all based on clinical assessment of anthropometrics and symptoms. The ESS and the STOP-BANG questionnaire showed the highest sensitivity ${ }^{34}$. Data from the HypnoLaus cohort were recently used to develop the NoSAS score based on the assessment of risk factors such as neck circumference, body mass index, snoring, age, and gender, and results were verified in an additional cohort ${ }^{35}$. However, screening for OSA by questionnaires is far from perfect, since their sensitivity and specificity vary according to the population under study, the type of sleep test used for assessment, or presence of comorbidities ${ }^{36,37}$.

In clinical practice, subjective EDS is usually evaluated by the ESS, a questionnaire administered to the patient on the likelihood of falling asleep in any of eight situations, according to a score of 0 to 3 (from unlikely to very likely) ${ }^{33}$. Subjective EDS is considered to be present if the ESS score is at least 10 and severe if ESS is at least 16. The ESS score is a good estimate of EDS in symptomatic OSA patients but cannot be considered totally reliable. For example, the need to renew a driver's license and the fear of losing one's job as a truck driver are known causes of voluntary underreporting of EDS by the patient. Therefore, objective assessment of sleepiness is needed, as is a sleep study to assess the occurrence of OSA and its severity.

Objective evaluation of EDS by the Mean Sleep Latency Test (MSLT) or Maintenance of Wakefulness Test (MWT) after nocturnal polysomnography (PSG) in the sleep laboratory is not applicable in large numbers of patients. Moreover, nowadays, OSA diagnosis is often obtained by respiratory polygraphy (that is, by monitoring cardiorespiratory signals without sleep staging, which is necessary for MSLT or MWT obtained on the day after PSG). Whereas MSLT is not very sensitive in patients with OSA and shows several limitations ${ }^{38}$, MWT may better reflect the capability to maintain vigilance under monotonous driving such as on a freeway ${ }^{39-41}$, especially when prolonged trials are used (that is, 40 instead of the usual 20 minutes) ${ }^{42}$.

Driving simulators might represent a good diagnostic option, but they have not yet entered clinical practice and are mostly used for research purposes. Driving simulator tests yield a considerable amount of information; for example, they can measure deviation of lane position and reaction times ${ }^{43}$. Failure during simulated driving was associated with the following responses obtained in OSA patients filling out a detailed anonymous questionnaire on driving: the need to take a break after less than one hour of driving, the likelihood of feeling moderately to highly sleepy while driving, and the occurrence of nodding off while driving in the previous year ${ }^{44}$. Differences in ESS between patients failing or not failing at the driving simulator test were small, confirming the known finding that referred sleepiness at the wheel might be more useful than sleepiness in general to identify OSA patients at risk of accidents ${ }^{45}$. A recent systematic review comparing performance at driving simulators and occurrence of real driving accidents casts some doubt on the potential clinical impact of driving simulation to predict real accidents in the individual patient ${ }^{46}$. Twelve studies, which included small samples of subjects, were analyzed and used heterogeneous protocols and different simulators, indicating a strong need for further research in this field.

Other experimental studies have investigated possible predictors of sleepiness and driving performance in patients with OSA. Spectral analysis of sleep electroencephalography (EEG) ${ }^{47}$ 
or sophisticated analysis of EEG during wakefulness ${ }^{48,49}$ may provide sensitive markers of impaired driving performance. Eyelid movements and closure appear to be promising markers to detect sleepiness ${ }^{50-53}$ and have the advantage of being potentially used to identify a driver's EDS inside the vehicle with the use of sensors.

In conclusion, while the problem of driving safety in general, and in patients with OSA in particular, is currently investigated in different parts of the world, we are still in an early phase, since tests to be used on a large scale to assess fitness to drive with regard to EDS are lacking. Meanwhile, road safety campaigns and education of the general public about sleepiness at the wheel should be implemented at the national level to increase awareness, similar to what already happens regarding cell phone use or texting while driving, which are known to greatly increase the risk of car accidents ${ }^{54}$. In addition, the development of new technologies will likely improve vehicle safety by the use of sensors to alert the sleepy driver. OSA-related accidents can be prevented by OSA treatment in the large majority of cases, but patients seeking medical help account for only about one-fifth of OSA cases occurring in the general population, and a standardized protocol to identify previously unknown OSA cases at high risk of accidents is lacking. A joint Task Force of the European Respiratory Society and the European Sleep Research Society is currently at work to suggest the best available protocol to apply the EU Directive on Sleepiness while driving in patients with OSA and to suggest a research agenda to improve safety on the road in Europe ${ }^{55}$.

\section{Competing interests}

The author declares that she has no competing interests.

\section{Grant information}

The author(s) declared that no grants were involved in supporting this work.
1. Lévy $\mathrm{P}$, Kohler M, McNicholas WT, et al:: Obstructive sleep apnoea syndrome. Nat Rev Dis Primers. 2015; 1: 15015. PubMed Abstract | Publisher Full Text

2. Eckert DJ: Phenotypic approaches to obstructive sleep apnoea - New pathways for targeted therapy. Sleep Med Rev. 2016; pii: S1087-0792(16)30154-X PubMed Abstract | Publisher Full Text

3. F Senaratna CV, Perret JL, Lodge CJ, et al.: Prevalence of obstructive sleep apnea in the general population: A systematic review. Sleep Med Rev. 2017; 34 $70-81$.

PubMed Abstract | Publisher Full Text | F1000 Recommendation

4. $\quad$ F Heinzer R, Vat S, Marques-Vidal P, et al.: Prevalence of sleep-disordered breathing in the general population: the HypnoLaus study. Lancet Respir Med. 2015; 3(4): 310-8.

PubMed Abstract | Publisher Full Text | Free Full Text | F1000 Recommendation

5. Kribbs NB, Pack Al, Kline LR, et al: Objective measurement of patterns of nasa CPAP use by patients with obstructive sleep apnea. Am Rev Respir Dis. 1993; 147(4): 887-95.

PubMed Abstract | Publisher Full Text

6. F Pamidi S, Wroblewski K, Stepien M, et al.: Eight Hours of Nightly Continuous Positive Airway Pressure Treatment of Obstructive Sleep Apnea Improves Glucose Metabolism in Patients with Prediabetes. A Randomized Controlled Trial. Am J Respir Crit Care Med. 2015; 192(1): 96-105.

PubMed Abstract | Publisher Full Text | Free Full Text | F1000 Recommendation

7. Marklund M, Verbraecken J, Randerath W: Non-CPAP therapies in obstructive sleep apnoea: mandibular advancement device therapy. Eur Respir J. 2012; 39(5): 1241-7.

PubMed Abstract | Publisher Full Text

8. F Dorrity J, Wirtz N, Froymovich O, et al.: Genioglossal Advancement, Hyoid Suspension, Tongue Base Radiofrequency, and Endoscopic Partial Midline Glossectomy for Obstructive Sleep Apnea. Otolaryngol Clin North Am. 2016; 49(6): 1399-414.

PubMed Abstract | Publisher Full Text | F1000 Recommendation

9. Araghi $\mathrm{MH}, \mathrm{Chen} \mathrm{YF}$, Jagielski $\mathrm{A}$, et al.: Effectiveness of lifestyle interventions on obstructive sleep apnea (OSA): systematic review and meta-analysis. Sleep. 2013; 36(10): 1553-62, 1562A-1562E.

PubMed Abstract | Publisher Full Text | Free Full Text

10. F Fu Y, Xia Y, Yi H, et al.: Meta-analysis of all-cause and cardiovascular mortality in obstructive sleep apnea with or without continuous positive airway pressure treatment. Sleep Breath. 2017; 21(1): 181-9. PubMed Abstract | Publisher Full Text | F1000 Recommendation

11. $\mathrm{F}$ Lee $\mathrm{CH}$, Sethi R, Li R, et al:: Obstructive Sleep Apnea and Cardiovascular Events After Percutaneous Coronary Intervention. Circulation. 2016; 133(21)
2008-17.

PubMed Abstract | Publisher Full Text | F1000 Recommendation

12. F McEvoy RD, Antic NA, Heeley E, et al:: CPAP for Prevention of Cardiovascular Events in Obstructive Sleep Apnea. N Engl J Med. 2016; 375(10): 919-31.

PubMed Abstract | Publisher Full Text | F1000 Recommendation

13. $\mathrm{F}$ Peker $\mathrm{Y}$, Glantz H, Eulenburg C, et al.: Effect of Positive Airway Pressure on Cardiovascular Outcomes in Coronary Artery Disease Patients with Nonsleepy Obstructive Sleep Apnea. The RICCADSA Randomized Controlled Trial. Am J Respir Crit Care Med. 2016; 194(5): 613-20.

PubMed Abstract | Publisher Full Text | F1000 Recommendation

14. F Abuzaid AS, Al Ashry HS, Elbadawi A, et al.: Meta-Analysis of Cardiovascular Outcomes With Continuous Positive Airway Pressure Therapy in Patients With Obstructive Sleep Apnea. Am J Cardiol. 2017; 120(4): 693-9. PubMed Abstract | Publisher Full Text | F1000 Recommendation

15. F Bioulac S, Franchi JM, Arnaud M, et al:: Risk of Motor Vehicle Accidents Related to Sleepiness at the Wheel: A Systematic Review and Meta-Analysis. Sleep. 2017; 40(10): zsx134.

PubMed Abstract | Publisher Full Text | F1000 Recommendation

16. Gonçalves M, Amici R, Lucas R, et al:: Sleepiness at the wheel across Europe: a survey of 19 countries. J Sleep Res. 2015; 24(3): 242-53. PubMed Abstract | Publisher Full Text

17. Tregear S, Reston J, Schoelles $\mathrm{K}$, et al:: Obstructive sleep apnea and risk of motor vehicle crash: systematic review and meta-analysis. J Clin Sleep Med. 2009; 5(6): 573-81.

PubMed Abstract | Free Full Text

18. F Garbarino S, Guglielmi O, Sanna A, et al.: Risk of Occupational Accidents in Workers with Obstructive Sleep Apnea: Systematic Review and Meta-analysis. Sleep. 2016; 39(6): 1211-8.

PubMed Abstract | Publisher Full Text | Free Full Text | F1000 Recommendation

19. Hirsch Allen AJ, Park JE, Daniele PR, et al.: Obstructive sleep apnoea and frequency of occupational injury. Thorax. 2016; 71(7): 664-6. PubMed Abstract | Publisher Full Text

20. F Karimi M, Hedner J, Lombardi C, et al:: Driving habits and risk factors for traffic accidents among sleep apnea patients--a European multi-centre cohort study. J Sleep Res. 2014; 23(6): 689-99.

PubMed Abstract | Publisher Full Text | F1000 Recommendation

21. F Karimi M, Hedner J, Häbel H, et al:: Sleep apnea-related risk of motor vehicle accidents is reduced by continuous positive airway pressure: Swedish Traffic Accident Registry data. Sleep. 2015; 38(3): 341-9.

PubMed Abstract | Publisher Full Text | Free Full Text | F1000 Recommendation 
22. Commission Directive 2014/85/EU, July 1st, 2014, on Driving licenses. Official J Eur Union. L194/10, 2014

Reference Source

23. F Tregear S, Reston J, Schoelles K, et al:: Continuous positive airway pressure reduces risk of motor vehicle crash among drivers with obstructive sleep apnea: systematic review and meta-analysis. Sleep. 2010; 33(10): 1373-80. PubMed Abstract | Free Full Text | F1000 Recommendation

24. Antonopoulos CN, Sergentanis TN, Daskalopoulou SS, et al.: Nasal continuous positive airway pressure (nCPAP) treatment for obstructive sleep apnea, road traffic accidents and driving simulator performance: a meta-analysis. Sleep Med Rev. 2011; 15(5): 301-10.

PubMed Abstract | Publisher Full Text

25. F Dwarakanath $\mathrm{A}$, Twiddy $\mathrm{M}$, Ghosh $\mathrm{D}$, et al:: Variability in clinicians' opinions regarding fitness to drive in patients with obstructive sleep apnoea syndrome (OSAS). Thorax. 2015; 70(5): 495-7.

PubMed Abstract | Publisher Full Text | F1000 Recommendation

26. F Gurubhagavatula I, Sullivan S, Meoli A, et al:: Management of Obstructive Sleep Apnea in Commercial Motor Vehicle Operators: Recommendations of the AASM Sleep and Transportation Safety Awareness Task Force. J Clin Sleep Med. 2017; 13(5): 745-58.

PubMed Abstract | Publisher Full Text | Free Full Text | F1000 Recommendation

27. F Burks SV, Anderson JE, Bombyk M, et al:: Nonadherence with EmployerMandated Sleep Apnea Treatment and Increased Risk of Serious Truck Crashes. Sleep. 2016; 39(5): 967-75.

PubMed Abstract | Publisher Full Text | Free Full Text | F1000 Recommendation

28. Thomas RJ: Sleepiness and Driving: Multidimensional Legal, Social, Technological, and Biological Challenges. Sleep. 2016; 39(5): 961-2. PubMed Abstract | Publisher Full Text | Free Full Text

29. F Terán-Santos J, Egea Santaolalla C, Montserrat JM, et al.: Sleep Apnea and Driving. Recommendations for Interpreting Spanish Regulations for Drivers. Arch Bronconeumol. 2017; 53(6): 336-41.

PubMed Abstract | Publisher Full Text | F1000 Recommendation

30. Netzer NC, Stoohs RA, Netzer CM, et al.: Using the Berlin Questionnaire to identify patients at risk for the sleep apnea syndrome. Ann Intern Med. 1999; 131(7): 485-491.

PubMed Abstract | Publisher Full Text

31. Chung $F$, Subramanyam R, Liao $P$, et al:: High STOP-Bang score indicates a high probability of obstructive sleep apnoea. Br J Anaesth. 2012; 108(5): 768-775. PubMed Abstract | Publisher Full Text | Free Full Text

32. Chung F, Yegneswaran B, Liao P, et al.: STOP questionnaire: a tool to screen patients for obstructive sleep apnea. Anesthesiology. 2008; 108(5): 812-821. PubMed Abstract | Publisher Full Text

33. Johns MW: A new method for measuring daytime sleepiness: the Epworth sleepiness scale. Sleep. 1991; 14(6): 540-545. PubMed Abstract | Publisher Full Text

34. F Chiu HY, Chen PY, Chuang LP, et al.: Diagnostic accuracy of the Berlin questionnaire, STOP-BANG, STOP, and Epworth sleepiness scale in detecting obstructive sleep apnea: A bivariate meta-analysis. Sleep Med Rev. 2017; 36: 57-70.

PubMed Abstract | Publisher Full Text | F1000 Recommendation

35. F Marti-Soler H, Hirotsu C, Marques-Vidal P, et al.: The NoSAS score for screening of sleep-disordered breathing: a derivation and validation study. Lancet Respir Med. 2016; 4(9): 742-8.

PubMed Abstract | Publisher Full Text | F1000 Recommendation

36. F Turnbull CD, Stradling JR: To screen or not to screen for obstructive sleep apnea, that is the question. Sleep Med Rev. 2017; 36: 125-127. PubMed Abstract | Publisher Full Text | F1000 Recommendation

37. F McNicholas WT: Screening for sleep-disordered breathing: the continuing search for a reliable predictive questionnaire. Lancet Respir Med. 2016; 4(9): 683-5.

PubMed Abstract | Publisher Full Text | F1000 Recommendation

38. Bonnet MH: ACNS clinical controversy: MSLT and MWT have limited clinical utility. J Clin Neurophysiol. 2006; 23(1): 50-8.

PubMed Abstract | Publisher Full Text

39. Sagaspe $\mathrm{P}$, Taillard J, Chaumet G, et al:: Maintenance of wakefulness test as a predictor of driving performance in patients with untreated obstructive sleep apnea. Sleep. 2007; 30(3): 327-30.

PubMed Abstract

40. Philip P, Sagaspe $\mathrm{P}$, Taillard J, et al.: Maintenance of Wakefulness Test, obstructive sleep apnea syndrome, and driving risk. Ann Neurol. 2008; 64(4): 410-6. PubMed Abstract | Publisher Full Text

41. Gieteling EW, Bakker MS, Hoekema A, et al:: Impaired driving simulation in patients with Periodic Limb Movement Disorder and patients with Obstructive Sleep Apnea Syndrome. Sleep Med. 2012; 13(5): 517-23. PubMed Abstract | Publisher Full Text

42. Arzi L, Shreter R, El-Ad B, et al:: Forty- versus 20-minute trials of the maintenance of wakefulness test regimen for licensing of drivers. $J$ Clin Sleep Med. 2009; 5(1): 57-62.

PubMed Abstract | Free Full Text

43. Ghosh D, Jamson SL, Baxter PD, et al:: Continuous measures of driving performance on an advanced office-based driving simulator can be used to predict simulator task failure in patients with obstructive sleep apnoea syndrome. Thorax. 2012; 67(9): 815-21. PubMed Abstract | Publisher Full Text

44. F Ghosh D, Jamson SL, Baxter PD, et al:: Factors that affect simulated driving in patients with obstructive sleep apnoea. ERJ Open Res. 2015 1(2): pii: 00074-2015

PubMed Abstract | Publisher Full Text | Free Full Text | F1000 Recommendation

45. Masa JF, Rubio M, Findley LJ: Habitually sleepy drivers have a high frequency of automobile crashes associated with respiratory disorders during sleep. Am J Respir Crit Care Med. 2000; 162(4 Pt 1): 1407-12. PubMed Abstract | Publisher Full Text

46. F Schreier DR, Banks C, Mathis J: Driving simulators in the clinical assessment of fitness to drive in sleepy individuals: A systematic review. Sleep Med Rev. 2017; pii: S1087-0792(17)30094-1. PubMed Abstract | Publisher Full Text | F1000 Recommendation

47. F Vakulin A, D'Rozario A, Kim JW, et al.: Quantitative sleep EEG and polysomnographic predictors of driving simulator performance in obstructive sleep apnea. Clin Neurophysiol. 2016; 127(2): 1428-35. PubMed Abstract | Publisher Full Text | F1000 Recommendation

48. F D'Rozario AL, Cross NE, Vakulin A, et al.: Quantitative electroencephalogram measures in adult obstructive sleep apnea - Potential biomarkers of neurobehavioural functioning. Sleep Med Rev. 2017; 36: 29-42. PubMed Abstract | Publisher Full Text | F1000 Recommendation

49. F Jawinski P, Kittel J, Sander C, et al:: Recorded and Reported Sleepiness: The Association Between Brain Arousal in Resting State and Subjective Daytime Sleepiness. Sleep. 2017; 40(7): zsx099. PubMed Abstract | Publisher Full Text | F1000 Recommendation

50. Wilkinson VE, Jackson ML, Westlake J, et al:: The accuracy of eyelid movement parameters for drowsiness detection. J Clin Sleep Med. 2013; 9(12): 1315-24. PubMed Abstract | Publisher Full Text | Free Full Text

51. F Alvaro PK, Jackson ML, Berlowitz DJ, et al:: Prolonged Eyelid Closure Episodes during Sleep Deprivation in Professional Drivers. J Clin Sleep Med. 2016; 12(8): 1099-103.

PubMed Abstract | Publisher Full Text | Free Full Text | F1000 Recommendation

52. F Jackson ML, Raj S, Croft RJ, et al.: Slow eyelid closure as a measure of driver drowsiness and its relationship to performance. Traffic Inj Prev. 2016: 17(3): 251-7.

PubMed Abstract | Publisher Full Text | F1000 Recommendation

53. Ahlstrom C, Nyström M, Holmqvist $\mathrm{K}$, et al.: Fit-for-duty test for estimation of drivers' sleepiness level: Eye movements improve the sleep/wake predictor. Transportation Research Part C: Emerging Technologies. 2013; 26: 20-32. Publisher Full Text

54. Simmons SM, Hicks A, Caird JK: Safety-critical event risk associated with cell phone tasks as measured in naturalistic driving studies: A systematic review and meta-analysis. Accid Anal Prev. 2016; 87: 161-9.

PubMed Abstract | Publisher Full Text

55. Bonsignore MR, Randerath W, Riha R, et al:: New rules on driver licensing for patients with obstructive sleep apnoea: EU Directive 2014/85/EU. Eur Respir J. 2016; 47(1): 39-41.

PubMed Abstract | Publisher Full Text 


\section{Open Peer Review}

\section{Current Peer Review Status:}

\section{Editorial Note on the Review Process}

Faculty Reviews are review articles written by the prestigious Members of Faculty Opinions. The articles are commissioned and peer reviewed before publication to ensure that the final, published version is comprehensive and accessible. The reviewers who approved the final version are listed with their names and affiliations.

\section{The reviewers who approved this article are:}

\section{Version 1}

\section{Luigi Ferini-Strambi}

Department of Clinical Neuroscience, Sleep Disorders Center, Università Vita-Salute San Raffaele, Milan, Italy

Competing Interests: No competing interests were disclosed.

\section{Joaquin Terán Santos} Respiratory Dept, Hospital Universitario de Burgos, Burgos, Spain

Competing Interests: No competing interests were disclosed.

\section{Mark Elliott}

Department of Respiratory Medicine, St James University Hospital, Leeds, UK

Competing Interests: No competing interests were disclosed.

The benefits of publishing with F1000Research:

- Your article is published within days, with no editorial bias

- You can publish traditional articles, null/negative results, case reports, data notes and more

- The peer review process is transparent and collaborative

- Your article is indexed in PubMed after passing peer review

- Dedicated customer support at every stage

For pre-submission enquiries, contact research@f1000.com 